\title{
Employment and Income Effects of Tourism Activities in the Tourist City of Livingstone in Zambia
}

\section{Syed Ali}

Department of Economics, Mulungushi University, Kabwe, Zambia

Email address:

Profali_1951@yahoo.com

To cite this article:

Syed Ali. Employment and Income Effects of Tourism Activities in the Tourist City of Livingstone in Zambia. International Journal of Economics, Finance and Management Sciences. Vol. 3, No. 5, 2015, pp. 577-582. doi: 10.11648/j.ijefm.20150305.29

\begin{abstract}
This study was conducted in the tourist city of Livingstone in Zambia to find out the effects of tourism activities i.e., hotel, tourist guide, transport service/boat captain and business (curios), on employment and income. A total of 90 respondents were selected. Estimation of the factors influencing income and employment involved the use of Ordinary Least Square models. The study concluded that the effect of all the tourism activities under study on income and employment were positive and significant. The study recommended that the Government should encourage the private sector to create an enabling environment for investments in tourism activities and provide supporting infrastructure for those investments. It was also suggested to establish "One-Stop" shops, like in Mauritius, where investors can find a centralized source of information and guidance for investing. Research and Training facilities should be provided for the development of tourism sector.
\end{abstract}

Keywords: Tourism Activities, Employment, Income, Education, Infrastructure, One-Stop Shops, Research, Training

\section{Introduction}

Tourism is a powerful vehicle for economic growth and job creation all over the world [9]. Tourism Activities have impact on economic growth, job creation and development. At present, international tourism contributes US\$ 1.5 trillion to global trade representing $30 \%$ of the world's service exports, a share that goes up to $45 \%$ in least developed countries. Tourism also plays a key role in fostering multicultural understanding and contributing to the preservation of cultural and natural heritage. This linkage is particularly relevant as the international community prepares to adopt the post 2015 Agenda with Sustainable Development Goals (SDGs) where Tourism has been identified as a sector that "Creates Jobs and Promotes local culture and products" [6]. The UN Secretary General, Bank Ki Moon [2] stated in his message on the occasion of the World Tourism Day, "Let us work together to maximize the immense potential of Tourism to drive inclusive economic growth, protect the environment and promote sustainable development and a life of dignity for all".

The international tourist arrivals increased by $4.3 \%$ in 2014, reaching a total 1133 million after topping the 1 billion mark in 2012. The international tourism receipts reached US\$ 1245 billion worldwide in 2014, up from US\$ 1197 billion in 2013, corresponding to an increase of 3.7\% in real terms, taking into account exchange rate fluctuations and inflation [7].

The Tourism is one of the leading job creators in the world. The industry employs more than 98 million people directly, representing over 3 percent of all employment. When indirect and induced impacts are included, the industry contributes to around one in every eleven jobs worldwide. The share of world employment in Travel and Tourism is greater than that for the auto manufacturing and chemicals manufacturing industries combined, across every region of the world [10].

Being a socio-economic phenomenon, tourism acts both as an engine of economic development and a social force, impacting a wide range of industries. Thus, as a demand-side phenomenon, tourism refers to the activities of visitors and their role in the acquisition of goods and services. At the same time, tourism can also be viewed from the supply-side and it will then be understood as the set of productive activities that cater mainly for visitors. As such, tourism is an important source of job creation and countries are interested in its development for this reason. One job in tourism generates 1.5 jobs elsewhere [8]. The tourism industry is facing a number of infrastructure and investment challenges in Africa that are holding back its progress [4]. A study in Zambia by the Natural Resources Consultative Forum found 
that a $\$ 250,000$ investment in the tourism sector generates 182 full-time formal jobs. This is nearly $40 \%$ more than the same investment in Agriculture and over 50\% more than in mining [3].

Tourism is one of the priority sectors for development in Zambia and has the potential to be a major contributor to socio-economic development of the country. The performance still remained far below potential because the challenges of poor and inadequate infrastructure, limited investment, fragmented operations, policy and legal framework, inadequate marketing and limited skilled manpower.

During the Fifth National Development Plan (2006-2010) the contribution to GDP was constant at 3.1 percent over the plan period. There was a notable increase in international tourist arrivals from a target of 736,450 to an average of 793,999 over the period. There was also notable increase in accommodation for the tourism industry from 500 establishments in 2005 to 940 in 2009 and from 10,900 bed spaces in 2005 to 19000 in 2009 . Average direct earnings increased from US\$ 174 million in 2005 to US\$ 200 million in 2009. In terms of employment level, the sector employed 25,860 in 2009 from 19,650 in 2005. Despite these improvements, the sector still continued facing challenges of poor physical infrastructure particularly roads, railways, airports, telecommunications and accommodation facilities. Other challenges include inadequate quality training facilities and skilled manpower [5].

The table 1 shows performance indicators for the Sixth National Development Plan (SNDP).

Table 1. Performance Indicators for the SNDP period (2011-15).

\begin{tabular}{llllll}
\hline Key Performance Indicators & Baseline 2009 & $\mathbf{2 0 1 1}$ & $\mathbf{2 0 1 2}$ & $\mathbf{2 0 1 3}$ & $\mathbf{2 0 1 4}$ \\
\hline Tourist Arrivals International & 709,948 & 810,000 & 920,800 & $1,030,800$ & $1,140,000$ \\
Annual Direct Tourism Earnings (US\$ M) & 200 & 216 & 260 & 312 & 374 \\
Employment Levels & 27,412 & 29,000 & 31,000 & 36,000 & 41,000 \\
Bed space in the hospitality industry & 19,000 & 20,140 & 22,150 & 23,370 & 24,806 \\
Occupancy Rates (\%) & 60 & 62 & 65 & 68 & 71 \\
Length of stay for tourists (days) & 7 & 7 & 10 & 10 & 14 \\
\hline
\end{tabular}

Source: SNDP (2011-15), Ministry of Finance and Planning, January 2011, Lusaka.

The table 2 shows the Sector Budget and Financing during the SNDP period.

Table 2. Sector Budget and Financing during the SNDP period (in $K^{\prime}$ Billion).

\begin{tabular}{|c|c|c|c|c|c|}
\hline Programmes & 2011 & 2012 & 2013 & 2014 & 2015 \\
\hline $\begin{array}{l}\text { Tourism Marketing and } \\
\text { Promotion }\end{array}$ & 11.3 & 21.5 & 25.3 & 25.5 & 25.5 \\
\hline $\begin{array}{l}\text { Tourism Product } \\
\text { Development and Research }\end{array}$ & 0.2 & 1.0 & 1.5 & 1.5 & 1.5 \\
\hline Product Quality & 1.5 & 1.2 & 1.0 & 1.0 & 1.0 \\
\hline Tourism Infrastructure & & & & & \\
\hline $\begin{array}{l}\text { Development and } \\
\text { Investment Promotion }\end{array}$ & 22.0 & 9.4 & 11.0 & 11.0 & 11.0 \\
\hline $\begin{array}{l}\text { Tourism Skills } \\
\text { Development }\end{array}$ & 0.5 & 0.5 & 0.6 & 0.8 & 0.9 \\
\hline $\begin{array}{l}\text { Arts and Culture } \\
\text { Infrastructure }\end{array}$ & 5.0 & 6.8 & 7.2 & 7.8 & 9.0 \\
\hline Creative Industries & 1.9 & 2.8 & 3.1 & 3.5 & 5.0 \\
\hline Total & 41.9 & 43.3 & 49.9 & 51.1 & 53.9 \\
\hline
\end{tabular}

Source: SNDP (2011-15), Ministry of Finance and Planning, January, 2011, Lusaka

Though the tourism industry plays very important role in providing employment and income in Zambia, there are very few research studies on unearthing the potentiality of tourism activities in economic development. This research study is an attempt to fill the gap in the existing literature on the potentiality of employment and income in tourism activities in the tourist city of Livingstone. This study also helps the planners and administrators to prepare plans and programmes to solve the challenges faced by this industry.

\section{Objectives}

The objectives of the study are to:

1. Find out the effects of Tourism Activities on income and employment

2. Investigate the effect of Education and Training on income and employment

3. Ascertain the impact of sales on net income in hotel and business (curios) activities

4. Know the sources of credit to the tourism industry

\section{Methodology}

The study area was Livingstone in Zambia .The study used stratified random sampling technique for selecting the sample. A total of four tourist activities were selected, i.e., hotel, tourist guide, transport service/boat captain and business (Curios). A total of 90 respondents -5 from hotel, 30 from tourist guide, 21 from transport service/boat captain and 34 from business (Curios) - were selected. The required data were collected through questionnaire and interview with the respondents. The data were collected in June, 2015. The income was calculated for month and the employment was measured in man-hours per month. The direct impact of tourism activities on income and employment were taken into account. The study used Eviews statistical package. Estimation of the factors influencing income and employment involved the use of ordinary least square regression models. 


\section{Model Specification and Estimation}

Estimation of the factors influencing net income of the respondents involved the use of ordinary least square regression techniques and specified by equations:

$$
Y=\beta_{1}+\beta 2 d 2+\beta 3 d 3+\beta 4 d 4+\mu
$$

Where $\mathrm{Y}=$ Income; $\beta 1=$ income from hotel; $\beta 2=$ income from tourist guide; $\mathrm{d} 2=$ tourist guide; $\beta 3=$ income from transport service/boat captain; $\mathrm{d} 3=$ transport service/boat captain; $\beta 4=$ income from business (curios) and $d 4=$ business (curios).

When $\mathrm{d} 2=1 ; \mathrm{d} 2=0$ for any other tourism activity: When $\mathrm{d} 3=1 ; \mathrm{d} 3=0$ for any other tourism activity; and when $\mathrm{d} 4=1$; $\mathrm{d} 4=0$ for any other tourism activity.

The income from hotel activity $(\beta 1)$ is the benchmark. $\mu=$ error term associated with data collection which was assumed to be normally distributed with zero mean and constant variance.

Estimation of the factors influencing employment involved the use of ordinary least square regression techniques and specified by equations.

$$
\mathrm{E}=\alpha 1+\alpha 2 \mathrm{e} 2+\alpha 3 \mathrm{e} 3+\alpha 4 \mathrm{e} 4+\mu
$$

Where $\mathrm{E}=$ Employment; $\alpha 1=$ employment in hotel; $\alpha 2=$ employment in tourist guide; e2=tourist guide; $\alpha 3=$ employment in transport service/boat captain; e3=transport service/boat captain; $\alpha 4=$ employment in business (curios) and e4= business (curios)

When e2=1; e2=0 for any other tourism activity: When e3 $=1$; e3=0 for any other tourism activity and when e4=1, e4 $=0$ for any other tourism activity.

The employment from hotel activity $(\alpha 1)$ is the benchmark. $\mu=$ error term associated with data collection which was assumed to be normally distributed with zero mean and constant variance.

\section{Data Analysis and Discussion}

\subsection{Effect of Tourism Activities on Income}

The table 3 shows the Effect of tourism activities on Income:

Table 3. Effect of Tourism Activities on Income.

\begin{tabular}{llll}
\hline Variable & Coefficient & Std. Error & t-Statistic \\
\hline C & 11130.00 & 2022.205 & 5.503893 \\
Tourist Guide & -8086.667 & 2184.231 & -3.702295 \\
Transport Service/Boat Captain & -6734.762 & 2250.102 & -2.993092 \\
Business (Curios) & -10536.44 & 2165.798 & -4.864923 \\
R-squared & 0.243852 & Mean dependent var & 0.0004 \\
Adjusted R-squared & 0.217475 & S.D. dependent var & 0.0036 \\
S.E. of regression & 4521.788 & Akaike info criterion & 2882.567 \\
Sum squared resid & $1.76 \mathrm{E}+09$ & Schwarz criterion & 5111.649 \\
Log likelihood & -883.1583 & F-statistic & 19.71463 \\
Durbin-Watson stat & 1.297168 & Prob(F-statistic) & 19.82573 \\
\hline
\end{tabular}

Source: Primary data

All the Tourism Activities were significant in explaining the impact on income. The $\mathrm{R}$ square of the model was 24 percent. Hotel activity had highest impact on income, i.e., $\mathrm{K}$ 11130. The income from Tourist Guide activity was below the income from the hotel by $\mathrm{K} 8086.667$. The income from Transport Service/Boat Captain was below the income from hotel by K 6734.762. The income from Business (Curios) was below the income from hotel activity by K 10536.44 .

\subsection{Effect of Tourism Activities on Employment}

The table 4 shows the effect of tourism activities on employment.

\begin{tabular}{|c|c|c|c|c|}
\hline Variable & Coefficient & Std. Error & t-Statistic & Prob. \\
\hline $\mathrm{C}$ & 2160.000 & 141.0952 & 15.30881 & 0.0000 \\
\hline Tourist Guide & -1920.000 & 152.4002 & -12.59841 & 0.0000 \\
\hline Business (Curios) & -1856.471 & 151.1141 & -12.28522 & 0.0000 \\
\hline R-squared & 0.665518 & \multicolumn{2}{|c|}{ Mean dependent var } & 370.6667 \\
\hline Adjusted R-squared & 0.653850 & \multicolumn{2}{|c|}{ S.D. dependent var } & 536.2475 \\
\hline Sum squared resid & 8560376. & \multicolumn{2}{|c|}{ Schwarz criterion } & 14.50071 \\
\hline Log likelihood & -643.5325 & \multicolumn{2}{|l|}{ F-statistic } & 57.03807 \\
\hline Durbin-Watson stat & 3.371538 & \multicolumn{2}{|c|}{ Prob(F-statistic) } & 0.000000 \\
\hline
\end{tabular}

Table 4. Effect of Tourism Activities on Employment.

Source: Primary data 
All the Tourism Activities were significant in explaining the effect on employment. The R square of the model was 66.5 percent. The Hotel Activity had highest effect on employment, i.e. 2160 man-hours per month. This confirms the results of the study by Ajala [1]. The effect on employment from Tourist Guide and Transport Service/Boat Captain was less than the hotel activity by 1920 man-hours per month. The effect of Business (Curios) on employment was below the hotel service by 1856.471 man-hours per month.

\subsection{Effect of Education on Income}

The table 5 shows the effect of education on income.

Table 5. Effect of Education on Income.

\begin{tabular}{lllc}
\hline Variable & Coefficient & Std. Error & t-Statistic \\
\hline C & 480.0000 & 5114.053 & 0.093859 \\
Primary level & 761.2105 & 5246.908 & 0.145078 \\
Secondary level & 2718.136 & 5171.841 & 0.9254 \\
Tertiary level & 3160.385 & 5211.473 & 0.8850 \\
R-squared & 0.032799 & Mean dependent var & 0.606428 \\
Adjusted R-squared & -0.000941 & S.D. dependent var & 0.6005 \\
S.E. of regression & 5114.053 & Akaike info criterion & 2885 \\
Sum squared resid & $2.25 \mathrm{E}+09$ & Schwarz criterion & 5111.649 \\
Log likelihood & -894.2359 & F-statistic & 19.96080 \\
Durbin-Watson stat & 2.003984 & Prob(F-statistic) & 20.07190 \\
\hline
\end{tabular}

Source: Primary data

The effect of education on income was positive. When there was no education the income was $\mathrm{K} 480$. But when one has education at primary level earns income K 761.2105 more than the illiterate person. One with secondary level of education and tertiary level of education earns K 2718.136 and K 3160.385 more than the illiterate person.

\subsection{Effect of Education on Employment}

The table 6 shows the effect of education on employment.

Table 6. Effect of Education on Employment.

\begin{tabular}{lllc}
\hline Variable & Coefficient & Std. Error & t-Statistic \\
\hline C & 240.0000 & 542.8124 & 0.442142 \\
Primary level & 101.0526 & 556.9138 & 0.181451 \\
Secondary level & 98.18182 & 548.9461 & 0.6595 \\
Tertiary level & 212.3077 & 553.1526 & 0.8564 \\
R-squared & 0.009904 & Mean dependent var & 0.8585 \\
Adjusted R-squared & -0.024635 & S.D. dependent var & 0.7021 \\
S.E. of regression & 542.8124 & Akaike info criterion & 370.6667 \\
Sum squared resid & 25339495 & Schwarz criterion & 178 \\
Log likelihood & -692.3674 & F-statistic & 15.58593 \\
Durbin-Watson stat & 0.924472 & Prob(F-statistic) & 0.286746 \\
\hline
\end{tabular}

Source: Primary data

When there was no education the employment was only 240 man-hours per month. But when one has primary level of education the employment level was 101.0526 man-hours more than the illiterate. When one had secondary level of education, the employment was 98.18 man-hours higher than the illiterate. And when had tertiary level of education, the employment was 212.307 man-hours more than illiterate person.

Since the R squared was 0.0099 , the model did not explain the variation between education and employment.

\subsection{Effect of Training on Income}

The table 7 shows the effect of training on income

Table 7. Effect of Training on Income.

\begin{tabular}{|c|c|c|c|c|}
\hline Variable & Coefficient & Std. Error & t-Statistic & Prob. \\
\hline $\mathrm{C}$ & 987.9392 & 741.5688 & 1.332229 & 0.1862 \\
\hline TRAINING & 218.8915 & 62.45874 & 3.504577 & 0.0007 \\
\hline R-squared & 0.122475 & \multicolumn{2}{|c|}{ Mean dependent var } & 2882.567 \\
\hline Adjusted R-squared & 0.112503 & \multicolumn{2}{|c|}{ S.D. dependent var } & 5111.649 \\
\hline S.E. of regression & 4815.534 & \multicolumn{2}{|c|}{ Akaike info criterion } & 19.81905 \\
\hline Sum squared resid & $2.04 \mathrm{E}+09$ & \multicolumn{2}{|c|}{ Schwarz criterion } & 19.87460 \\
\hline Log likelihood & -889.8574 & \multicolumn{2}{|l|}{ F-statistic } & 12.28206 \\
\hline Durbin-Watson stat & 1.059690 & \multicolumn{2}{|c|}{ Prob(F-statistic) } & 0.000722 \\
\hline
\end{tabular}

Source: Primary data 
The effect of training on income was positive and significant. When there was no training the income was only $\mathrm{K}$ 987.93. When training increased by one month, the income increased by K 218.89 .

\subsection{Effect of Training on Employment}

The table 8 shows the effect of training on employment.

Table 8. Effect of Training on Employment.

\begin{tabular}{llll}
\hline Variable & Coefficient & Std. Error & t-Statistic \\
\hline C & 363.7201 & 83.04117 & Prob. \\
TRAINING & 0.802559 & 6.994155 & 0.0000 \\
R-squared & 0.000150 & Mean dependent var & 0.114747 \\
Adjusted R-squared & -0.011212 & S.D. dependent var & 37097 \\
S.E. of regression & 539.2454 & Akaike info criterion & 536.2475 \\
Sum squared resid & 25589131 & Schwarz criterion & 15.44019 \\
Log likelihood & -692.8086 & F-statistic & 15.49574 \\
Durbin-Watson stat & 1.306505 & Prob(F-statistic) & 0.013167 \\
\hline
\end{tabular}

Source: Primary data

The effect of training on employment was positive but not significant. Since the R squared value was 0.000150 , the model did not explain any variation between training and employment. When there was no training the employment level was 363.72 man-hours. When training increased by one month the employment increased by only 0.8025 man-hours.

\subsection{Sources of Credit}

The table 9 shows the sources of credit to tourism activities.

Table 9. Sources of Credit to Tourism Activities.

\begin{tabular}{lll}
\hline Source & Amount in Kwacha & Percentage \\
\hline Bank & -- & -- \\
Micro Finance & -- & -- \\
Co-operatives & -- & -- \\
Friends/Relatives & 9000 & 100 \\
Total & 9000 & 100 \\
\hline
\end{tabular}

Source: Primary data

The above table 9 shows that the only source of credit to tourism activities was the friends/relatives. The average credit from this source was only K 100 (9000/90). There was no role of banks, micro finance, and co-operatives in providing credit to the tourism activities:

\subsection{Ratio of Net Income to Sales in Hotel and Business (Curios) Activities}

The table 10 shows the ratio of net income to sales in hotel and business (curios) activities

Table 10. Ratio of Net Income to Sales in Hotel and Business (Curios) Activities.

\begin{tabular}{llll}
\hline Activity & $\begin{array}{l}\text { Total Sales per } \\
\text { month (in Kwacha) }\end{array}$ & $\begin{array}{l}\text { Net Income per } \\
\text { month (In Kwacha) }\end{array}$ & $\begin{array}{l}\text { Net income to } \\
\text { Sales ratio }\end{array}$ \\
\hline $\begin{array}{l}\text { Hotel } \\
\text { Business } \\
\text { (Curios) }\end{array}$ & 93,400 & 55650 & 0.60 \\
Total & 139,772 & 20,184 & 0.43 \\
\hline
\end{tabular}

Source: Primary data
The value of total sales in hotel and business (curios) activities per month was $\mathrm{K} 139,772$, the net income per month was $\mathrm{K} 75,831$ and the net income to sales ratio was 0.54 in both activities.

The net income to sales per month was higher in hotel activity (0.60), whereas it was lower in business (curios) activity (0.43).

\section{Conclusions}

The study concluded that the impact of all the tourism activities under study on income and employment were positive and significant. The hotel activity had higher impact on income and employment than the other tourism activities. The income from hotel activity was K. 11,130 per month and the employment increased by 2160 man-hours per month. The impact of education on income and employment was positive but not significant. The impact of training on income was positive and significant. The impact of training on employment was positive but not significant. When training increased by one month, the employment increased by only 0.8025 man-hours per month.

The only source of credit to tourism activities was friends and relatives. The average credit from this source was only $\mathrm{K}$ 100. There was no role of banks or other financial institutions in providing credit to tourism activities. The ratio of net income to sales in hotel and business (curios) activities together was 0.54 . The net income to sales per month was higher in hotel activity (0.60) than in business (curios) activity (0.43).

\section{Recommendations}

Since the tourism activities had positive and significant impact on employment and income, the following measures are suggested for the development of tourism industry to eradicate poverty and un-employment in Zambia.

1. The Government should have strong will power to develop tourism sector and take lead in creating institutions and coordinating mechanisms to maintain a dialogue with all stake holders. 
2. The Government should encourage the private sector to create an enabling environment for investments in tourism activities and provide supporting infrastructure for those investments.

3. Investors should be provided with needed information through "one-stop" shops, like in Mauritius, where investors can find a centralized source of information and guidance for investing.

4. Connectivity should be improved within countries and regions and access by road and by air to the region, whether through private sector entrepreneurship, government or both.

5. The constraints on tourism development like lack of access to finance for investment, taxes on tourism investments, low level of tourism skills, lack of security and safety, high rates of crimes, public health issues, visa requirements and red tape $\&$ bureaucracy should be resolved.

6. The sub-sectors of tourism, i.e., financial, economic, social and environmental, should be strengthened for sustained tourism development.

7. Research and training facilities should be provided for the development of tourism sector.

\section{References}

[1] Ajala, O.A (2008): Employment and Income Potentiality of Tourism Development in Amhara Region Ethiopia, Ethiopian Journal of Environmental Studies and Management, Vol. 1, No. 2, June, 2008. pp.74-82.
[2] Ban Ki Moon (2015): World Tourism Day: Celebrating the million opportunities brought about by the Tourism Sector, Press Release by UNWTO, Madrid, Spain, 24 September, 2015, Press Release No. 15066.

[3] Hamilton, K., G. Tembo., G. Sinyenga., S. Bandopadhyay., A. Pope., B. Guilon., B. Muwele., S. Mann and J.M. Pavy (2007): The Real Economic Impact of Nature Tourism in Zambia, Lusaka: Natural Resources Consultative Forum.

[4] Rochelle Turner and Zachary Sears (2013): The Travel and Tourism as a driver of Employment growth, the travel and tourism competitiveness Report, 2013, p. 65.

[5] SNDP (2011): Sixth National Development Plan, Ministry of Finance and National Planning, Lusaka, January 2011, pp. 142-148.

[6] UNWTO (2015): Press Release on $24^{\text {th }}$ September, 2015, UNWTO, Madrid, Spain, Press Release No.15066.

[7] UNWTO (2015): Tourism Highlights 2015 Edition, p. 5.

[8] UNWTO (2014): Measuring Employment in the Tourism Industries: Guide with Best Practices, UNWTO, Madrid, Spain, pp. 16-29.

[9] World Bank (2014): Tourism in Africa, Harnessing Tourism for Growth and Improved Livelihoods, Washington D.C, p- 1.

[10] World Economic Forum (2013): The Travel and Tourism Competitiveness Report: Travel and Tourism as a Driver of Employment Growth, World Economic Forum, 2013, pp. 6369. 